\title{
Relation of Food to Disease*
}

$\mathrm{M}$ ANY diseases, ranging from different types of poisoning to deficiency diseases, are caused by defects or impurities in the food supply of a population: at times they may even occur in epidemics. Cure may be brought about by changing the food supply or by adding a missing factor to the diet; in other cases, only medical treatment is of value. Prevention, as always, is better than cure. With an adequate dietary of pure foods, most of these diseases can be abolished or their incidence greatly reduced. A review of the disorders associated with the ingestion of food, which was given by $\mathrm{Mr}$. S. Dixon, the public analyst of the City of Cardiff, to a joint meeting of the South Wales Section of the Institute of Chemistry and the local section of the Society of Chernical Industry, at Cardiff, in February 1932, has now been issued as a small brochure and provides a useful and interesting summary of our knowledge of the subject.

The deficiency diseases are first briefly referred to, especially those associated with a deficient intake of one or other of the vitamins, such as rickets and scurvy, or in other countries beriberi and pellagra. Chemical poisons of non-bacterial origin may be inorganie substances which have gained aceess to the food through faulty methods of manufacture, or organic compounds present in certain animals or plants which are not foods in the true sense but may be consumed through inadvertence. Mushroom poisoning still occurs, although epidemic ergotism is now rare. An epidemic of the latter, however, occurred in England five years ago among Jewish immigrants from Central Europe who lived on rye bread.

The chief metallic poison which may contaminate foodstuffs is arsenie, which may find its way into the "The Relation of Food to Disease". By Stanley Dixon. Pp. 38. (London: The Institute of Chemistry of Great Britain and Ireland, 1982.) food through the use of material prepared with the aid of impure sulphuric acid : it may also be found on fruit which has been sprayed with an insecticide containing lead arsenite and once was inadvertently used as a dusting powder for boiled sweets. Antimony, lead and zinc may also produce poisoning, but small quantities of tin and copper do not usually have any deleterious effects.

Various diseases are conveyed to human beings by food which contains pathogenic bacteria. Milk may be responsible for the spread of typhoid, scarlet fever, diphtheria, bacillary dysentery, tonsillitis, and undulant fever. Surgical tuberculosis in children, when caused by bovine tubercle bacilli, is due to the ingestion of these organisms in the milk. Other articles of food which may be infected with the organisms of infectious diseases are ice-cream, meat, and shell-fish, especially mussels and oysters. Another group of diseases is due to contamination of the food with organisms of the Salmonella group, dysentery bacilli or $B$. botulinus. These are classified under the term, "Bacterial Food Poisoning". It is not considered that 'ptomaine" poisoning has any scientific basis, although two types of poisoning are due to toxins formed by organisms, namely, botulism, and a rare form of mussel poisoning which appears to be due to chemical poisons elaborated in the shell fish by the vital activity of bacteria derived from sewage-contaminated surroundings.

Animal parasites are not responsible for much disease in Great Britain, though they assume greater importance in the tropics and in countries where food is imperfectly cooked. Tapeworm infestations, in their larval or adult forms, and trichinosis, from the ingestion of infested pork, are the commonest.

In conclusion, attention may be directed to food idiosyncrasy, which illustrates in the modern manner that what is one man's food may be another man's poison.

\section{Chemistry of Australian Timbers*}

$\mathrm{M}$ SSRS. W. E. COHEN, A. L. Baldock and A. G. Charles have produced a useful pamphlet on the chemical composition of the woods of the ironbark group of eucalypts, which constitutes Technical Paper No. 4 of the Division of Forest Products of the Council of Scientific and Industrial Research. The important species upon which the study was based are the ironbarks Eucalyptus sider. oxylon, siderophloia, crebra and paniculata together with a less important species $E$. fergusoni and the grey gums $E$. propinqua and $E$. punctata.

The first four mentioned are the commercially important ironbarks and have a wide geographical distribution, the group spreading over the eastern States, Queensland, New South Wales and Victoria; the remaining species have a more restricted distribution. The eucalypts are in great demand for all types of heavy structural works. They are used in railway and bridge construction, shipbuilding, coach and waggon building, houses, railway sleepers, wharf decking and so forth.

In a foreword to the pamphlet, Dr. Boas, chief of the Division of Forest Products, states that in this

- Commonwealth of Australia: Council of Seientifle and Industrial Research. Pamphlet No. 32, Part 2. (Melbourne: H. J. Green, 1932.) paper the authors describe the first extended chemical study of a group of timbers of the genus Eucalyptus. The importance now being attached to this chemical study of wood is summarised as follows: "There is a general trend in forest products research towards utilising wood substances after some form of chemical transformation. Other investigations involve altering the physical characteristics of wood to increase its resistance to fire, and to reduce in seasoned timber the absorption and loss of moisture with consequent shrinkage and swelling. Such proposals and those associated with converting wood into paper, artificial silk, lacquers, ete., must have their foundation in a fuller knowledge of the chemistry of timber. This Division has consequently planned work in this field, almost untouched as far as Australian timbers are concerned."

At present, in the systematic study of the chemistry of the timbers, consideration is being given to those groups containing woods, which, in addition to being very similar in general characteristics and therefore easily confused, are not easy to separate by means of their anatomical features. The object of the investigation discussed in the pamphlet, which was commenced in July 1930, was to obtain data on 